\title{
PERBANDINGAN HASIL BELAJAR FISIKA PESERTA DIDIK BERDASARKAN KARAKTER INTROVERT DAN EKSTROVERT
}

\section{THE COMPARISON OF STUDENTS' PHYSICS LEARNING OUTCOMES BASED ON INTROVERT AND EXTROVERT CHARACTERS}

\author{
Ahmad Ilham Alayyubi'1), Kasmawati2), A. Jusriana ${ }^{3)}$ \\ 1,2,3)Fakultas Tarbiyah dan Keguruan Universitas Islam Negeri Alauddin Makassar \\ alayyubiahmad.007@gmail.com ${ }^{1}$, kasmawati@uin-alauddin.ac.id ${ }^{2}$, \\ andijusrianafisikanm@yahoo.com ${ }^{3}$ )
}

\begin{abstract}
Abstrak
Penelitian ini termasuk jenis penelitian ex post facto bertujuan untuk membandingkan hasil belajar fisika berdasarkan karakter introvert dan ekstrovert peserta didik. Populasi dalam penelitian ini adalah seluruh peserta didik kelas XI MA Guppi tahun ajaran 2019/2020 yang berjumlah 51 peserta didik. Sampel terdiri atas dua kelas dengan jumlah peserta didik kelas A sebanyak 25 orang dan peserta didik kelas B sebanyak 26 orang. Instrumen penelitian yang digunakan yaitu angket psikologi (Jung's Type Indicator Test) dan teknik dokumentasi. Teknik analisis data yang digunakan yaitu analisis statistik deskriptif dan inferensial. Dari hasil analisis deskiptif perbandingan hasil belajar peserta didik yang berkepribadian introvert dan ekstrovert yang paling dominan di MA Guppi Samata memiliki kepribadian ekstrovert sebanyak 26 orang (65\%) dibandingkan dengan kepribadian introvert sebanyak 14 orang (35\%) dan rata-rata hasil belajar peserta didik yang memiliki karakter introvert $(82,62)$ lebih rendah dibandingkan hasil belajar peserta didik yang memiliki kepribadian ekstrovert $(83,87)$. Hasil analisis memperoleh nilai ChiSquare 4,541 dengan taraf signifikan 5\% Assymp. Sig 0,338 > 0,05 yang berarti tidak ada perbedaan yang signifikan antara tipe kepribadian ekstrovert dan introvert terhadap hasil belajar fisika kelas XI MA Guppi, sehingga disimpulkan bahwa baik peserta didik dengan tipe kepribadian ekstrovert maupun introvert keduanya mempunyai peluang yang sama dalam meningkatkan hasil belajar.
\end{abstract}

Kata Kunci: introvert, ekstrovert, hasil belajar

\begin{abstract}
This research is an ex post facto research which aims to compare the learning outcomes of physics based on the introvert and extrovert character of students. The population in this study were all students of class XI MA Guppi for the 2019/2020 academic year, totaling 51 students. The sample consisted of two classes with 25 class $A$ students and 26 class $B$ students. The research instruments used were psychological questionnaires Jung's Type Indicator Test) and documentation techniques. The data analysis technique used is descriptive and inferential statistical analysis. From the results of descriptive analysis, the comparison of the learning outcomes of students with introverted and extroverted personalities, the most dominant in MA Guppi Samata, has an extrovert personality of 26 people (65\%) compared to the introverted personalities of 14 people (35\%) and the average learning outcomes of students. those who have introverted characters (82.62) are lower than the learning outcomes of students who have extrovert personalities (83.87). The results of the analysis obtained the Chi-Square value of 4.541 with a significant level of 5\% Assymp. Sig $0.338>0.05$, which means that there is no significant difference between extrovert and introvert personality types on the learning outcomes of physics class XI MA Guppi, so it is
\end{abstract}


concluded that both students with extrovert and introvert personality types both have the same opportunity to improve learning outcomes.

Keywords: introvert, extrovert, learning outcomes

How to Cite: Alayyubi, A. I., Kasmawati \& Jusriana, A. (2020). Perbandingan hasil belajar fisika peserta didik berdasarkan karakter introvert dan ekstrovert. Al asma: Journal of Islamic Education, 2(2), 202-209.

\section{PENDAHULUAN}

Pendidikan sangat penting dan menjadi penentu dalam kehidupan manusia. Dengan pendidikan, manusia dapat mengembangkan semua potensi mereka. Pendidikan juga merupakan persediaan warga yang ditakrifkan sebagai aktivitas yang dirancang untuk melengkapkan pelajar untuk menjadi warga negara yang baik. Sudah tentu, istilah yang baik di sini adalah relatif, bergantung pada tujuan nasional setiap bangsa yang mempunyai falsafah hidup yang berbeda. Salah satu faktor terpenting dalam menjalani kehidupan bermasyarakat adalah pendidikan.

Menurut Kunandar (2017), aktivitas pembelajaran adalah keterlibatan peserta didik pada proses pembelajaran, dimana proses tersebut tidak dapat dipisahkan dari komponen lain yang saling berinteraksi antara satu sama lain. Salah satu komponen dalam proses pembelajaran, yaitu mengenai pendidikan watak, pendidikan watak yang relevan akan menjadi proses pembelajaran menjadi efektif dan efisien. Pendidikan watak harus menjadi bahagian yang mesti mendapat perhatian pendidik dalam setiap pelajaran. Aktivitas dalam pembelajaran di sekolah, kita berhadapan dengan beberapa ciri berbagai pelajar. Terdapat pelajar yang dapat menjalankan aktivitas pembelajaran mereka dengan lancar dan berjaya tanpa mengalami kesukaran, tetapi di sisi lain, terdapat juga banyak pelajar yang mengalami berbagai kesukaran dalam pembelajaran mereka. Kesukaran belajar pelajar ditunjukkan oleh adanya halangan tertentu untuk mencapai hasil pembelajaran, dan boleh berupa psikologi, sosiologi, dan fisiologi, sehingga pada akhirnya dapat menyebabkan pencapaian pembelajaran yang mereka capai berada di bawah yang seharusnya. Rahman (2016) mengungkapkan bahwa kepribadian didefinisikan sebagai keseluruhan pola pikiran, perasaan, dan perilaku yang sering digunakan dalam usaha adaptasi yang terus menerus terhadap hidupnya. Dalam klasifikasinya, terdapat banyak versi tipe kepribadian salah satunya adalah tipe kepribadian introvert, ekstrovert dan ambivert.

Gazzaniga \& Heartherton (2017) mengungkapkan bahwa kepribadian merupakan karakteristik seseorang dengan pikiran, perasaan, dan perilaku yang dibentuk oleh waktu dan pengalaman individu tersebut. Carl Gustuv Jung dalam (W, 2013), dia mengklasifikasikan jenis kepribadian menjadi tiga, yaitu jenis kepribadian introvert, ekstrovert dan ambivert. Orang dengan kepribadian introvert cenderung hidup dalam dunia mereka sendiri. Interaksi mereka dengan dunia luar tidak baik, mereka mempunyai kepribadian tertutup, sukar untuk bersosial dengan orang lain, dan sering menarik diri dari situasi sibuk, sehingga orang yang mempunyai kepribadian ini kurang dapat bergaul dengan persekitaran mereka yang menyebabkan mereka mudah cemas. Ia berbeda dengan orang-orang dengan kepribadian exrovert, interaksi mereka dengan dunia luar sangat baik, mudah bergaul, mempunyai tingkah laku aktif dan tindakan mereka 
dipengaruhi oleh dunia luar, dan terbuka. Walau bagaimanapun, introvert dan ekstrovert adalah seperti dua sisi yang berbeda . Jadi, setiap orang mempunyai kecenderungan untuk bersikap introvert dan ekstrovert, cuma kadang-kadang salah satunya lebih dominan. Sementara itu, seseorang yang mempunyai keseimbangan dalam dimensi introvert dan ekstrovert disebut ambivert. Berdasarkan tiga jenis kepribadian yang diklasifikasikan oleh Carl Gstuv Jung, penyelidik hanya memfokuskan pada dua jenis yang berbeda, yaitu jenis kepribadian introvert dan ekstrovert, karena individu yang mempunyai kepribadian ambivert selalu berubah minat, mengubah tindakan atau keputusan, kadang-kadang bersikap introvert, kadang-kadang juga mempunyai ciri kepribadian. tingkah laku ekstrovert bergantung kepada keadaan dan keadaan. Oleh karena itu, sukar untuk membedakan individu dengan kepribadian ambivert.

Menurut Anees \& Hambali (2018), pendidikan watak adalah pendidikan yang bertujuan untuk membentuk kepribadian seseorang yang hasilnya terlihat dalam tindakan nyata seseorang yaitu perilaku yang baik dan jujur, tanggung jawab, dan lain sebagainya. Menurut C.G. Jung dalam W (2013), ada sekumpulan orang yang ketika berhadapan dengan situasi tertentu pada awalnya menarik diri sedikit, seolah-olah berbisik "tidak" dan hanya beberapa saat kemudian dapat bertindak balas. Ada kumpulan lain yang, dalam menghadapi situasi yang sama, segera bertindak balas, yakin bahwa tingkah laku mereka betul. Terdapat kumpulan lain juga yang kedua dari tingkah laku di atas adalah milik mereka. Kumpulan pertama dicirikan oleh hubungan negatif dengan objek dan kumpulan kedua dicirikan oleh hubungan positif, kumpulan pertama dapat disamakan dengan kepribadian introvert, yang kedua dengan kepribadian ekstrovert dan kepribadian ketiga, yaitu ambivert.

Wengrum (2018) mengatakan bahwa peserta didik yang berkepribadian introvert dan ekstrovert memiliki prestasi yang berbeda dalam berbicara. Introvert adalah karakter individu yang berorientasi pada ide, emosi, dan kesan dan dapat dikategorikan sebagai peserta didik yang berpikiran tertutup (Laney, 2017). Artinya mereka lebih suka bekerja secara mandiri daripada bekerja secara kelompok, sedangkan ekstrovert adalah karakter individu yang berorientasi pada aktivitas, orang, dan hal-hal di luar individu, mereka secara aktif ikut terlibat dengan sekelompok orang karena mereka cenderung banyak bicara dalam kehidupan sehari-hari. Oleh karena itu, Suparman (2019) menyatakan bahwa peserta didik ekstrovert cenderung menjadi pembicara yang lebih baik dari introvert.

Ciri yang dapat dikenali juga dari tipe kepribadian introvert menurut Catrunada dalam Sylene (2018), yaitu kecenderungan mudah tersinggung, perasaan mudah merasa disakiti, mudah gugup, perasaan rendah diri, mudah melamun, gangguan tidur, intelegensi relatif tinggi, perbendaharaan kata baik, konsisten, teliti tapi lambat, kaku dalam bersikap, dan kurang suka lelucon. Adapun ciri yang dapat dikenali juga dari tipe ekstrovert menurut Kuntjojo dalam Sylene (2018), yaitu meliputi intelegensi relatif rendah, perbendaharaan kata kurang, inkonsistensi pada pendirian, cepat mengambil keputusan tapi kurang teliti, fleksibel, dan menyukai yang humoris.

Kepribadian ambivert adalah seseorang yang memiliki keseimbangan dalam dimensi introvert dan ekstrovert. Orang dengan tipe kepribadian ambivert pada keadaan tertentu cenderung ekstrovert dan pada keadaan yang lain cenderung introvert, tergantung kebutuhan dan kondisi. Tipe kepribadian ambivert merupakan bentuk kepribadian yang 
kompleks. Kepribadian ambivert juga memiliki sifat khas dimana minat yang dimilikinya sering berubah, tindakan atau keputusan berubah-ubah, kadang berkepribadian ekstrovert dan kadang berkepribadian introvert (Sylene, 2018).

Mulyadi (2018) dalam peneyelidikannya menyebutkan bahwa ciri-ciri introvert yaitu suka konsentrasi tinggi, perhatian yang baik terhadap detail, keinginan mereka untuk mendengarkan daripada berbicara berbeda daripada orang yang mempunyai jenis kepribadian ekstrovert, sebaliknya dari jenis kepribadian introvert. Akibatnya dalam pendidikan dapat mempengaruhi hasil pembelajaran. Kegiatan pendidikan di sekolah bukan hanya sekolah pakar, dimana pelajar lebih banyak mendengar, tetapi ada juga aktivitas perbincangan yang memerlukan pelajar untuk berbicara dan menyampaikan apa yang mereka pahami. Perbedaan ini menyebabkan orang dengan jenis kepribadian introvert dan ekstrovert mempunyai cara mereka sendiri untuk memupuk tabiat belajar sehingga mereka boleh dikatakan sebagai ahli akademik yang bagus. Menurut Lestari (2013), karakter introvert merasa tidak nyaman ketika berinteraksi dengan banyak orang sehingga mereka lebih senang menghabiskan waktu sendiri seperti membaca buku, menulis cerita atau mendengarkan musik. Di sisi lain, peserta didik ekstrovert bekerja paling baik di dalam kelas ketika sedang berdiskusi, karena mereka suka berbicara dan bekerja secara berkelompok.

Rahman (2016) mengungkapkan, kemampuan berkomunikasi secara efektif akan membuat pendengar mendengarkan apa yang dikatakan, memahami, menyetujui atau menolak dengan pemahaman yang benar dan memperoleh umpan balik dari pendengar. Hal ini menjadi kelemahan dari tipe kepribadian introvert. Dimana peserta didik yang berkepribadian introvert kebanyakan diam, yang akan kesulitan untuk mengikuti proses pembelajaran diskusi dan pada prakteknya yang akan berimbas pada kemampuan pemahaman terhadap materi yang telah di pelajaran.

Berdasarkan uraian di atas, peneliti memaparkan bagaimana membedakan dua sikap hidup yang berbeda, yaitu dua cara bereaksi terhadap suatu keadaaan dianggap cukup jelas dan meluas sehingga dapat dilukiskan sebagai sesuatu yang khusus, dua sikap tersebut itu adalah introvert dan ekstrovert maka dari itu peneliti tertarik untuk mencoba melakukan penelitian dengan judul "Perbandingan Hasil Belajar Peserta Didik Berdasarkan Karakter Introvert dan Ekstrovert Peserta Didik kelas XI MA Guppi” dengan tujuan untuk mengetahui perbedaan hasil belajar peserta didik berdasarkan karakter introvert dan ekstrovert peserta didik kelas XI MA Guppi.

\section{METODE PENELITIAN}

Penelitian ini termasuk jenis penelitian ex post facto untuk menggambarkan perbandingan hasil belajar peserta didik berdasarkan karakter introvert dan ekstrovert peserta didik kelas XI MA Guppi. Populasi dalam penelitian ini adalah seluruh peserta didik kelas XI MA Guppi yang berjumlah 51 orang dari 2 kelas. (sumber data sekolah tahun ajaran 2019/2020). Sampel merupakan sampel jenuh yaitu seluruh populasi terdiri atas 25 peserta didik untuk kelas XIA dan 26 peserta didik kelas XIB. Selanjutnya penelitian menggunakan desain penelitian yaitu The Criterion Group Design. Desain ini pada dasarnya melibatkan pemilihan dua kelompok penelitian yang berbeda dan membandingkannya dalam satu variabel atau beberapa variabel yang akan diteliti. 
Teknik pengumpulan data menggunakan tes kepribadian (personality test). Tes ini digunakan untuk mengukur kepribadian seseorang. Untuk memperoleh data tipe kepribadian introvert dan ekstrovert, penulis menggunakan alat ukur dari Jung's Type Indicator Test. Teknik penskoran untuk mengetahui tipe kepribadian introvert atau ekstrovert pada peserta didik adalah dengan cara memberikan skor 1 untuk setiap jawaban "Ya" dan memberi skor 0 untuk setiap jawaban "Tidak" pada pernyataan ekstrovert. Demikian pula sebaliknya, memberi skor 0 untuk setiap jawaban "Ya" dan memberi skor 1 untuk setiap jawaban "Tidak" pada pernyataan introvert. Jung's Type Indicator Test memiliki 36 pernyataan ekstrovert dan 34 pernyataan introvert sehingga peserta didik yang memiliki skor $\geq 36$ termasuk ke dalam tipe kepribadian ekstrovert, sedangkan peserta didik yang memiliki skor $\leq 35$ termasuk ke dalam tipe kepribadian introvert.

Tabel 1. Penggolongan Tipe Kepribadian Ekstrovert atau Introvert

\begin{tabular}{cccc}
\hline Pernyatan & Ya & Tidak & $\boldsymbol{\Sigma}$ \\
\hline Ekstrovert & 1 & 0 & $\geq 36$ \\
Introvert & 0 & 1 & $\leq 35$ \\
\hline
\end{tabular}

Berdasarkan tabel 1, semakin tinggi skor yang diperoleh peserta didik maka dapat diintepretasikan bahwa peserta didik tersebut cenderung mempunyai tipe kepribadian ekstrovert dan sebaliknya semakin rendah skor yang diperoleh, maka peserta didik semakin mengarah pada tipe kepribadian introvert.

Analisis yang digunakan pada penelitian ini adalalah analisis deskriptif, analisis deskriptif pada penelitian ini bertujuan untuk menggambarkan hasil belajar dari peserta didik kelas XI MA Guppi. Pengelompokan tersebut dilakukan kedalam 5 kategori: sangat tinggi, tinggi, sedang, rendah, sangat rendah. Pedoman pengkategorian hasil belajar peserta didik introvert dan peserta didik ekstrovert yang digunakan dalam penelitian ini adalah analisis dengan menggunakan statistik deskriptif.

\section{HASIL DAN PEMBAHASAN}

Analisis Deskriptif Hasil Belajar Fisika Peserta Didik Kelas XI Madrasah Aliyah Guppi Samata Berdasarkan Karakteristik Introvert

Tabel 2. Hasil Analisis Deskriptif Hasil Belajar Fisika Peserta Didik Berdasarkan Karakteristik Introvert

\begin{tabular}{lcc}
\hline \multirow{2}{*}{$\mathbf{N}$} & \multicolumn{1}{c}{ Valid } & 14 \\
\cline { 2 - 3 } & Missing & 0 \\
\hline Mean & & 82,62 \\
Std. Deviation & 2,35 \\
Variance & 5,55 \\
Minimum & 79,00 \\
Maximum & 87,00 \\
\hline
\end{tabular}

Kepribadian introvert yang dimiliki peserta didik kelas XI MA Guppi terdiri dari 14 orang atau 35\% dari 40 orang. Hasil belajar fisika yang dimiliki kepribadian introvert peserta didik kelas XI MA Guppi yaitu diperoleh nilai rata - rata 82,62.

Hasil belajar peserta didik yang berkepribadian introvert memiliki rata-rata hasil belajar 82,62. Hal ini disebabkan tenaga pendidik lebih tidak mengontrol dan melibat 
aktifkan peserta didik yang berkepribadian introvert ketimbang peserta didik yang berkepribadian ekstrovert. Hasil belajar peserta didik yang berkepribadian ekstrovert memiliki rata - rata hasil belajar 83.87 .

Analisis Deskriptif Hasil Belajar Fisika Peserta Didik Kelas XI Madrasah Aliyah Guppi Samata Berdasarkan Karakteristik Introvert

Tabel 3. Hasil Analisis Deskriptif Hasil Belajar Fisika Peserta Didik Berdasarkan

\begin{tabular}{lcc}
\multicolumn{3}{c}{ Karakteristik Ekstrovert } \\
\hline \multirow{2}{*}{$\mathbf{N}$} & Valid & 26 \\
\cline { 2 - 3 } & Missing & 0 \\
\hline Mean & 83,87 \\
Std. Deviation & 2,84 \\
Variance & 8,11 \\
Minimum & 80,00 \\
Maximum & 91,33 \\
\hline
\end{tabular}

Kepribadian ekstrovert yang dimiliki peserta didik kelas XI MA Guppi terdiri dari 26 orang atau $65 \%$ dari 40 orang. Hasil belajar fisika yang dimiliki kepribadian ekstrovert peserta didik kelas XI MA Guppi yaitu diperoleh nilai rata - rata 83.87.

Hasil belajar peserta didik yang berkepribadian ekstrovert memiliki rata-rata hasil belajar 83.87. Hal ini disebabkan tenaga pendidik lebih mengontrol dan melibat aktifkan peserta didik yang berkepribadian ekstrovert ketimbang peserta didik yang berkepribadian introvert. Hasil belajar peserta didik yang berkepribadian introvert memiliki rata - rata hasil belajar 82,62.

Analisis Kategorisasi Peserta Didik Berdasarkan Karakteristik Introvert dan Ekstrovert

Tabel 4. Hasil Kategorisasi Peserta Didik Berdasarkan Karakter Introvert dan Ekstrovert Peserta Didik Kelas XI MA Guppi Samata

\begin{tabular}{ccc}
\hline No & Kategori & Jumlah \\
\hline 1 & Introvert & 14 Orang \\
2 & Ekstrovert & 26 Orang \\
\hline
\end{tabular}

Berdasarkan tabel 4, terdapat peserta didik yang masuk kategori introvert sebanyak 14 orang dan peserta didik yang masuk kategori ekstrovert sebanayak 26 orang.

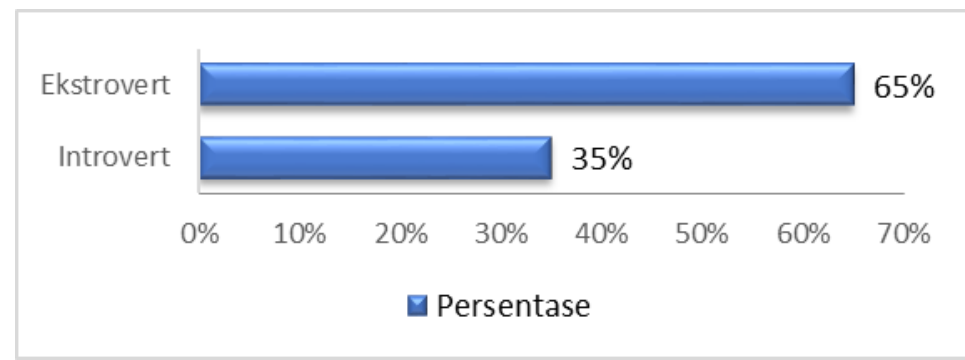

Gambar 1. Diagram Batang Kategorisasi Peserta Didik Berdasarkan Karakter Introvert dan Ekstrovert 
Berdasarkan gambar 1 terdapat peserta didik yang masuk kategori introvert sebanyak $35 \%$ dan peserta didik yang masuk kategori ekstrovert sebanyak $65 \%$. Adapun sampel lainnya yang berjumlah 11 orang, memiliki karakter ambivert namun tidak dimasukkan dalam persentase, karena individu yang mempunyai kepribadian ambivert selalu berubah minat, mengubah tindakan atau keputusan, kadang-kadang bersikap introvert, kadang-kadang juga mempunyai ciri kepribadian ekstrovert. Tingkah laku ekstrovert bergantung kepada keadaan dan keadaan. Oleh karena itu, sukar untuk membedakan individu dengan kepribadian ambivert.

Berdasarkan Tabel 3 dan Tabel 4 dapat dilihat bahwa tidak terdapat perbedaan yang signifikan antara kepribadian introvert dan ekstrovert. Nilai korelasi tidak memiliki hubungan yang positif terhadap hasil belajar fisika peserta didik. Hal tersebut disebabkan peserta didik yang berkepribadian ekstrovet lebih unggul pada pembelajaran yang menggunakan metode diskusi, praktek, pengetesan dalam bentuk lisan dan percaya diri dalam menyampaikan apa yang terdapat dalam pemikirannya, peserta didik ekstrovert senang menanyakan apa yang dia tidak ketahui tentang pelajaran fisika kepada teman maupun guru. Sedangkan peserta didik yang berkepribadian introvert lebih unggul pada pembelajaran yang menggunakan metode ceramah, pengetesan dalam bentuk tulisan dan cenderung lebih pasif, tidak berani dalam menyampaikan pemikiran atau ide yang dia miliki dan juga peserta didik introvert kurang memiliki keberanian untuk menanyakan apa yang tidak diketahuinya. Mereka lebih menyukai diam dari pada menanyakan apa yang tidak diketahui kepada orang lain.

Hal serupa juga diungkapkan oleh Aulia Bahtiar Rahman (2016) bahwa kemampuan berkomunikasi secara efektif akan membuat pendengar mendengarkan apa yang dikatakan, memahami, menyetujui atau menolak dengan pemahaman yang benar dan memperoleh umpan balik dari pendengar. Hal ini menjadi kelemahan dari tipe kepribadian introvert dimana peserta didik yang berkepribadian introvert kebanyakan diam, yang akan kesulitan untuk mengikuti proses pembelajaran diskusi dan pada prakteknya. Yang akan berimbas pada kemampuan pemahaman terhadap materi yang telah dipelajari.

Hasil belajar peserta didik yang berkepribadian ekstrovert memiliki rata-rata 83,87. Hal ini disebabkan tenaga pendidik lebih mengontrol dan melibat aktifkan peserta didik yang berkepribadian ekstrovert ketimbang peserta didik yang berkepribadian introvert. Hasil belajar peserta didik yang berkepribadian introvert memiliki rata - rata hasil belajar 82,62.

Black \& Sarah (2000) dalam penelitiannya juga menyebutkan bahwa orang- orang dengan tipe kepribadian introvert memiliki kebiasaan yang berbeda dengan orang - orang yang memiliki tipe kepribadian ekstrovert. Dimana tipe kerpibadian introvert cenderung lebih mendengarkan daripada banyak bicara. Mereka lebih banyak diam, sehingga sering disebut pendengar yang baik, lain halnya dengan tipe kepribadian ekstrovert kebalikan dari tipe kepribadian introvert. Akibat dari hal ini dalam pendidikan dapat mempengaruhi hasil belajarnya. Aulia Bahtiar Rahman (2016) mengungkapkan bahwa kegiatan pendidikan di sekolah bukan hanya pakar, dimana peserta didik lebih banyak mendengar namun terdapat juga kegiatan diskusi yang menuntut peserta didik untuk berbicara menyampaikan apa yang dipahami. Perbedaan tersebut mengakibatkan orang- orang 
dengan tipe kepribadian introvert maupun ekstrovert memiliki caranya sendiri dalam mengolah kebiasaan belajar sehingga ia dapat dikatakan sebagai akademisi yang sukses.

\section{SIMPULAN}

Berdasarkan hasil penelitian dan pembahasan diperoleh rata-rata hasil belajar peserta didik yang berkepribadian ekstrovert adalah 83,87 dan rata-rata hasil belajar peserta didik yang berkepribadian introvert adalah 82,62. Selain itu, diperoleh bahwa tidak terdapat perbedaan yang signifikan antara kepribadian ekstrovert dan introvert dalam hasil belajar peserta didik kelas XI MA Guppi Samata. Oleh karena itu, baik peserta didik dengan tipe kepribadian ekstrovert atau introvert keduanya mempunyai peluang yang sama dalam meningkatkan hasil belajar.

\section{DAFTAR PUSTAKA}

Anees, \& Hambali, A. (2018). Pendidikan karakter berbasis Al-Qur'an. Bandung: Simbiosa Rakatama.

Rahman, A. B. (2016). Hubungan tipe kepribadian introvert dengan prestasi belajar pada mahasiswa FK UII angkatan 2013. Universitas Islam Indonesia.

Black, B., \& Sarah, S. (2000). An investigation of study habits of introvert and ekstrovert. Liberal Arts and Science.

Gazzaniga, M. S., \& Heartherton, T. F. (2017). Psikologis ilmu: pikiran, otak, dan perilaku. New York: Amerika Serikat.

Kunandar. (2017). Penelitian tindakan kelas. Jakarta: Rajawali Pers.

Laney, M. (2017). Introvert keuntungan: bagaimana berkembang dalam seorang ekstrovert dunia. New York: Penerbitan Pekerja.

Lestari, A. (2013). Analisis hubungan ekstrovert-introvert kepribadian dan peserta didik kinerja berbicara. pontianak: Universitas Tanjungpura.

Mulyadi. (2018). A compartive study on introvert and ektrovert students personality in english listening scores. Jurnal Of English and Teaching, 2, 15.

Suparman, U. (2019). Psikolinguistik:teori penguasaan bahasa. Bandung: Afrino Raya.

Sylene, H. P. S. dan M. A. (2018). Hubungan antara kepribadian introvert dan ekstrovert dengan speaking skill mahasiswa prodi D III Keperawatan Tahun Akademik 2017/2018. Akademi Kesehatan Rustida.

W, S. S. (2013). Pengantar psikologi umum. Jakarta: Raja Grafindo Persada.

Wengrum, T. (2018). Komparatif Belajar dari peserta didik bacaan pemahaman untuk memahami teks naratif antara ekstrovert dan introvert peserta didik kepribadian pada kelas satu SMA Negeri 1 Seputih Banyak. Universitas Lampung. 